\title{
Haematological Problems and their Solutions in ABO-Incompatible Renal Transplants
}

\author{
C Gan ${ }^{1}$, I MacPhee ${ }^{2}$, P Andrews ${ }^{3}$, S Wiltshire ${ }^{4}$, M Morsy $^{2}$, S Heap $^{2}$ and N Kessaris ${ }^{5 *}$ \\ ${ }^{1}$ Department of Urology, Guy's Hospital, Great Maze Pond, London SE1 9RT, UK \\ ${ }^{2}$ St George's Hospital, St George's Renal and Transplant UnitLondon, UK \\ ${ }^{3}$ St Helier Hospital, South West Thames Renal \& Transplantation Unit, Surrey, Carshalton, UK \\ ${ }^{4}$ St George's Hospital, Blood Sciences, London, UK \\ ${ }^{5}$ Consultant Transplant Surgeon, Department of Nephrology and Transplantation, Guy's Hospital, UK and Honorary Senior Lecturer, King's College London, UK
}

*Corresponding author: Nicos Kessaris, Consultant Transplant Surgeon, Department of Nephrology and Transplantation, 6th Flood Borough Wing, Guy's Hospital, Great Maze Pond, London SE1 9RT, UK and Honorary Senior Lecturer, King's College London, UK, Tel: +44 (0) 2071887188 , Fax: +44 (0) 2071885646, E-mail: Nicos.Kessaris@gstt.nhs.uk

Received date: Mar 13, 2015, Accepted date: May 13, 2015, Published date: May 21, 2015

Copyright: ( 2015 Gan C et al. This is an open-access article distributed under the terms of the Creative Commons Attribution License, which permits unrestricted use, distribution, and reproduction in any medium, provided the original author and source are credited.

\begin{abstract}
We report on the haematological complications that we have encountered in implementing ABO-incompatible kidney transplantation, and the solutions we have used to overcome these.

We have performed $5 \mathrm{ABO}$-incompatible transplants with an immunosuppression protocol involving Rituximab, immunoadsorption, Tacrolimus, Mycophenolate Mofetil, and Prednisolone. Our protocol for blood product transfusion includes the use of high titer negative or washed red cells, high titer negative platelets or platelets in platelet suspension medium, and type $A B$ fresh frozen plasma.
\end{abstract}

Two patients required 2 units of washed red cells each and one required 2 units of platelets in platelet suspension medium at the time of surgery. The other two patients did not require any blood products. One of these, had an episode of acute vascular rejection which was successfully treated. All grafts are currently doing well with a mean serum creatinine concentration of $115 \mu \mathrm{mol} / \mathrm{L}(1.3 \mathrm{mg} / \mathrm{dL})$.

The immunoadsorption protocol employed in ABO-incompatible transplantation has a number of effects on red cell, white cell, and platelet counts that could potentially affect the outcome of the transplant. The use of suitably prepared blood products prevents transferring of incompatible antibodies, and allows transplantation to proceed without any increase in risk of graft rejection.

Keywords:

Immunoadsorption; Renal; Transplant; Washed red cells

\section{Introduction}

Renal transplantation has the greatest potential for improving quality of life in patients with end-stage renal failure compared with other means of renal replacement therapy. As of 31st March 2014, there were 5881 patients active on the renal transplant waiting list in the UK. Conversely, between 2013 and 2014, there have been 2142 deceased renal donor transplants, and 1114 living donor transplants in the UK [1]. This discrepancy between demand and the availability of donors has driven a variety of means of increasing the size of the living donor pool.

One such means has been by overcoming the immunological barrier of $\mathrm{ABO}$ blood group -incompatibility. Historically, $\mathrm{ABO}-$ incompatible renal transplants were only possible after splenectomy, multiple sessions of unselective plasmapheresis, and potent immunosuppressive protocols. This was associated with significant morbidity and mortality. A new protocol for ABO-incompatible renal transplants was introduced in Sweden in 2001, involving antigen specific immunoadsorption, Rituximab, and conventional Tacrolimus,
Mycophenolate Mofetil (MMF), and Prednisolone immunosuppression [2]. This has been found to be effective with no graft losses attributable to $\mathrm{ABO}$-incompatibility, and no rebound of antibodies. It has also been reported as being safe, with few complications resulting from the immunosuppressive regimen $[3,4]$.

Our transplant network has been performing ABO-incompatible renal transplants using the Swedish protocol with good outcome. However, it has become apparent that the immunosuppression protocol, particularly the immunoadsorption process, is associated with certain haematological complications that have been underreported thus far. This article reports some problems that we have encountered, and the solutions that we have adopted.

\section{Materials and Methods}

Five ABO-incompatible renal transplants with a mean of age 51.8 years (SD 3.7) were performed in our unit between September 2009 and February 2011 (Table 1). Our immunosuppression protocol for the recipient closely followed the Swedish protocol: $375 \mathrm{mg} / \mathrm{m} 2$ of Rituximab was given intravenously 30 days before transplant in an outpatient setting, after blood is taken for a final cross-match. 10 days prior to transplant, Tacrolimus (Prograf) was started at a daily dose of 
Citation: C Gan, I MacPhee, P Andrews, S Wiltshire, M Morsy et al. (2015) Haematological Problems and their Solutions in ABO-Incompatible Renal Transplants . Biol syst Open Access 4: 133. doi:10.4172/2329-6577.1000133

Page 2 of 3

$0.2 \mathrm{mg} / \mathrm{kg}$ orally, aiming for a trough Tacrolimus blood concentration of $10-15 \mathrm{ng} / \mathrm{mL}$, for the first month after transplantation. MMF $1 \mathrm{~g}$ twice daily and Prednisolone $30 \mathrm{mg}$ daily was also started at this time. Six, 5, 2, and 1 day prior to transplant, the recipients underwent immunoadsorption using Glycosorb columns (Glycorex Transplantation AB, Lund, Sweden) and the HF440 extracorporeal filtration device (L.IN.C. Medical Systems Ltd, Loddington, UK) to remove $\operatorname{IgG}$ and $\operatorname{IgM}$ antibodies against the $\mathrm{ABO}$ group of the potential donor. Heparin was used for the extracorporeal circuit and filter of the HF440 device. Acid-citrate dextrose was used during plasma adsorption as a local anticoagulant for the Glycorex column. Anti-A/B titers were checked before and after each apheresis session to monitor the decline. On the final day prior to transplant, $0.5 \mathrm{~g} / \mathrm{kg}$ of intravenous pooled human immunoglobulin (IVIG) was given after the last apheresis session. Anti-A/B titres were checked urgently one final time on the morning of transplantation. If the titers were less that or equal to $1 \mathrm{in} 8$, the transplant was carried out. If they were greater than 1 in 8 , then transplantation was postponed and more apheresis sessions performed.

\begin{tabular}{|c|c|c|c|c|c|c|c|c|c|}
\hline $\begin{array}{l}\text { Patient } \\
\text { number }\end{array}$ & $\begin{array}{l}\text { Age \& } \\
\text { Sex }\end{array}$ & $\begin{array}{l}\text { Mode of dialysis } \\
\text { before rituximab }\end{array}$ & $\begin{array}{l}\text { Donor } \\
\text { blood } \\
\text { group }\end{array}$ & $\begin{array}{l}\text { Recipient } \\
\text { blood group }\end{array}$ & $\begin{array}{l}\text { Highest Titre } \\
\text { before } \\
\text { rituximab }\end{array}$ & $\begin{array}{l}\text { Transplant } \\
\text { date }\end{array}$ & $\begin{array}{l}\text { Rejection } \\
\text { episodes }\end{array}$ & Other complications & $\begin{array}{l}\text { Last } \\
\text { Creatinine }\end{array}$ \\
\hline \multirow{3}{*}{1} & \multirow{3}{*}{$52 \mathrm{M}$} & \multirow{3}{*}{ Haemodialysis } & \multirow{3}{*}{ A1 } & \multirow{3}{*}{ B } & \multirow{3}{*}{$1: 16$} & \multirow{3}{*}{ Sep-09 } & \multirow{3}{*}{0} & \multirow{3}{*}{ No } & $117 \mu \mathrm{mol} / \mathrm{L}$ \\
\hline & & & & & & & & & $(1.32 \mathrm{mg} / \mathrm{dL})$ \\
\hline & & & & & & & & & $3 / 2 / 2012$ \\
\hline \multirow{3}{*}{2} & \multirow{3}{*}{$50 \mathrm{M}$} & \multirow{3}{*}{ Peritoneal dialysis } & \multirow{3}{*}{$A B$} & \multirow{3}{*}{0} & \multirow{3}{*}{$1: 64$} & \multirow{3}{*}{ Mar-10 } & 1 & Pulmonary embolism & $152 \mu \mathrm{mol} / \mathrm{L}$ \\
\hline & & & & & & & Banff 2B & Day 31 & $(1.72 \mathrm{mg} / \mathrm{dL})$ \\
\hline & & & & & & & Day 5 & $\begin{array}{l}\text { Treated with Warfarin for } \\
6 \text { months }\end{array}$ & $27 / 1 / 12$ \\
\hline \multirow{3}{*}{3} & \multirow{3}{*}{$47 \mathrm{~F}$} & \multirow{3}{*}{ Peritoneal dialysis } & \multirow{3}{*}{ B } & \multirow{3}{*}{0} & \multirow{3}{*}{$1: 256$} & \multirow{3}{*}{ Oct-10 } & 1 & Lymphocele & $85 \mu \mathrm{mol} / \mathrm{L}$ \\
\hline & & & & & & & Banff 1A & Drained December 2010 & $(0.96 \mathrm{mg} / \mathrm{dL})$ \\
\hline & & & & & & & $\begin{array}{l}1 \text { year \& } 29 \\
\text { days }\end{array}$ & $\begin{array}{lr}\text { BK virus treated with } \\
\text { reduction } & \text { of } \\
\text { immunosuppression } & \end{array}$ & $23 / 2 / 12$ \\
\hline \multirow{3}{*}{4} & \multirow{3}{*}{$53 \mathrm{M}$} & \multirow{3}{*}{ Predialysis } & \multirow{3}{*}{ A1B } & \multirow{3}{*}{ B } & \multirow{3}{*}{$1: 2$} & \multirow{3}{*}{ Nov-10 } & 1 & \multirow{3}{*}{ No } & $100 \mu \mathrm{mol} / \mathrm{L}$ \\
\hline & & & & & & & Banff 2A & & $(1.13 \mathrm{mg} / \mathrm{dL})$ \\
\hline & & & & & & & Day 51 & & $28 / 2 / 12$ \\
\hline \multirow{3}{*}{5} & \multirow{3}{*}{$57 \mathrm{~F}$} & \multirow{3}{*}{ Predialysis } & \multirow{3}{*}{ A1 } & \multirow{3}{*}{0} & & & & & $121 \mu \mathrm{mol} / \mathrm{L}$ \\
\hline & & & & & $1: 32$ & Feb-11 & 0 & UTI x1 & $(1.37 \mathrm{mg} / \mathrm{dL})$ \\
\hline & & & & & & & & & $16 / 9 / 11$ \\
\hline
\end{tabular}

Table 1: Table showing patient demographics and outcomes of the five patients following ABOI transplantation

Our policy for blood product transfusion in recipients of ABOincompatible renal transplant is as follows: In emergency situations, we use high titer negative red cell units which are ABO/D compatible with the recipient, high titer negative platelet units which are $\mathrm{ABO}$ compatible with the donor, and type $\mathrm{AB}$ fresh frozen plasma. In all other situations, we use washed red cells which are $\mathrm{ABO} / \mathrm{D}$ compatible with the recipient, platelets in platelet suspension medium which are $\mathrm{ABO}$ compatible with the recipient, and type $\mathrm{AB}$ fresh frozen plasma.

\section{Results}

We found that 2 of the 5 patients had a drop in haemoglobin from a maximum of $10.3 \mathrm{~g} / \mathrm{dL}$ and $10.2 \mathrm{~g} / \mathrm{dL}$ at the time of immunoadsorption to $8.7 \mathrm{~g} / \mathrm{dL}$ and $8.3 \mathrm{~g} / \mathrm{dL}$ on the morning of transplantation. Therefore, two units of washed red cells were given to each patient at time of surgery, as per our protocol.
One patient had a drop in platelet count from $118 \times 109$ /L before immunoadsorption to $74 \times 109$ on the morning of transplantation. This patient had only had 2 sessions of immunoadsorption prior to surgery as his titers were low. His PF4 heparin antibody for heparin induced thrombocytopaenia returned as weakly positive. He was given 2 units of platelets in platelet suspension medium at the time of transplantation.

We also observed that there was a significant rise in white blood cell counts after most immunoadsorption sessions. The highest rise was from $15 \times 109 / \mathrm{L}$ to $39 \times 109 / \mathrm{L}$ after a single session, and the rise was mainly a neutrophilia. However, all rises in white cell counts were transient.

Four transplants proceeded uneventfully with no post-operative rises in $\mathrm{ABO}$ antibody titers. The second recipient (patient 2), who had not required any blood products pre-operatively, experienced an episode of acute vascular rejection that required treatment with 
antithymocyte globulin. Patients 3 and 4 also had an episode of rejection each that required methylprednisolone. None of these were related to blood group antibodies. All grafts are currently doing very well with a mean serum creatinine concentration of $115 \mu \mathrm{mol} / \mathrm{L}, \mathrm{SD}$ $25.2,(1.28 \mathrm{mg} / \mathrm{dL}, \mathrm{SD} 0.29)$ at a maximum follow up of 2 years and 5 months.

There were no bleeding problems encountered peri-operatively, and no clinically relevant rises in white blood cell counts after transplantation. There was one episode of BK virus in patient 3. This was detected after the first year on repeat biopsy following treatment of rejection. It was treated with reduction of immunosuppression. Patient 5 had a simple urinary track infection (UTI) that was treated with antibiotics as an outpatient.

\section{Discussion}

The aim of an $\mathrm{ABO}$-incompatible renal transplant programme is to increase the living donor pool, but this has to be balanced with the potential problems associated with ABO-incompatibility. Most studies so far have found the immunosuppression protocol for $\mathrm{ABO}-$ incompatible transplants involving a regime of immunoadsorption, rituximab, and conventional immunosuppression to be safe and free of serious side effects [5]. However, we have shown that haematological complications do exist, and may have been under-reported in other studies.

Despite the need for blood product transfusion in 3 of our 5 patients, our use of washed red cells and platelets in platelet suspension medium seemed to be successful in not transferring any $\mathrm{ABO}$ incompatible antibodies to the recipient peri-operatively, and thus avoided any problems with antibody mediated graft rejection. However, the increased cost and time required to prepare such blood products have to be taken into consideration. Each unit of washed red cells costs US $\$ 1100$. The cost for a Glycosorb column for one immunoadsorption in ABO-incompatible transplantation is US $\$ 4400$. Even so, it is worth noting that $\mathrm{ABO}$-incompatible transplantation is still considered cost-effective when compared with the cost of longterm dialysis [6].

One way to help overcome the need for transfusions around the time of transplantation is by optimizing potential $\mathrm{ABO}$-incompatible recipients with haemoglobin $<10 \mathrm{~g} / \mathrm{dl}$ with iron and erythropoietin stimulating agents prior to starting immunoadsorption.

It is also important to note that leucocytosis following sessions of immunoadsorption occurred in all patients but appeared to be transient and not related to clinical infection. It was previously shown in 2001 that subjects receiving immunoadsorption for the treatment of autoimmune disorders also showed neutrophil activation, and it was suggested that this activation might play some role in immune modulation [7].

Haematological complications occurring as a result of the immunosuppressive protocol used in $\mathrm{ABO}$-incompatible renal transplants cannot be ignored, especially because the way in which they are managed can determine eventual graft success. We have shown in this paper that immunoadsorption has a number of effects on red cell count, white cell count, and platelet count, and can lead to the need for blood product transfusion prior to transplantation. The use of suitably prepared blood products at this time prevents transfer of incompatible antibodies, and allows transplantation to proceed without any increase in risk of graft rejection.

\section{Acknowledgements}

There was no financial support or relationships that pose conflict of interest by any of the authors. We would like to thank the Kidney Patient Association of St George's Hospital, London, UK for their financial help in acquiring the HF440 extracorporeal filtration device (L.IN.C. Medical Systems Ltd, Loddington, UK) for the local patients.

\section{References}

1. https://nhsbtmediaservices.blob.core.windows.net/organ-donationassets/pdfs/activity_report_2013_14.pdf

2. Tydén G, Kumlien G, Fehrman I (2003) Successful ABO-incompatible kidney transplantations without splenectomy usingantigen-specific immunoadsortion and Rituximab. Transplantation 76: 730-732

3. Tydén G, Kumlien G, Genberg H, Sandberg J, Lundgren T et al. (2005) ABO-incompatible kidney transplantation and rituximab. Transplantation Proceedings 37: 3286-3287

4. Tydén G, Donauer J, Wadström J Kumlien G, Wilpert J et al. (2007) Implementation of a protocol for ABO-incompatible kidney transplantation - A three-center experience with 60 consecutive transplantations. Transplantation 83: 1153-5

5. Genberg H, Kumlien G, Wennberg L, Tydén G (2010) Isoagglutinin adsorption in ABO-incompatible transplantation. Transfusion and Apheresis Science 43: 231-5

6. Tydén G (2006) Cost Effectiveness of ABO-incompatible Kidney Transplantations. Transplantation 82:166-167

7. Ota K, Shimizu Y, Ichikawa H (2000). Neutrophil activation in Immunoadsorption. Therapeutic Apheresis 4: 229-234 